Al Maal : Journal of Islamic Economics and Banking

http://jurnal.umt.ac.id/index.php/jieb

E-ISSN : $2580-3816$

Vol : 3 No. 1 Bulan Juli Tahun 2021

Hlm : $12-24$

DOI : $\quad$ : 10.31000/almaal.v3i1.4510

\title{
Pengaruh PKH dan BPNT terhadap Kemiskinan dengan Pertumbuhan Ekonomi Sebagai Variabel Moderasi
}

\author{
Lilik Rodhiatun Nadhifah ${ }^{\mathbf{1}^{*}}$, Nur Huri Mustofa ${ }^{2}$ \\ ${ }^{1,2}$ Ekonomi Syariah, Fakultas Ekonomi dan Bisnis Islam, IAIN Salatiga, Indonesia \\ *lilikrodhiatunnadhifah@gmail.com
}

\section{ABSTRACT}

This research is motivated by the number of poverty in Pucakwangi which is still quite high and deserves to receive Social Assistance. The purpose of this study was to determine the effect of the Family Hope Program (PKH), and the Non-Cash Assistance Program on poverty in Pucakwangi District with economic growth as a moderating variable. This research is a quantitative research with secondary data from related institutions such as BPS, Social Service, and Social Assistance Institutions. The data used is Time series data from 2018-2020. The population of this study is the entire Pucakwangi community receiving the Social Assistance Program for PKH and BPNT from 20 villages. By taking samples by means of purposive sampling from 20 audited villages multiplied quarterly to get a sample of 80. The analytical tool used is Eviews. The results showed that the Family Hope Program had a significant negative effect on poverty. The non-cash assistance program has a negative and significant effect on poverty. The hopeful family program which moderated economic growth had no significant negative effect. The Non-Cash Food Assistance Program moderated by economic growth has an insignificant negative effect.

Keywords: PKH; BPNT; Poverty; Economic Growth.

\section{ABSTRAK}

Penelitian ini dilatarbelakangi oleh jumlah kemiskinan di Pucakwangi yang tinggi dan layak menerima Bantuan Sosial. Tujuan penelitian ini untuk mengetahui pengaruh Program Keluarga Harapan (PKH), dan Program Bantuan Non Tunai terhadap kemiskinan di Kecamatan Pucakwangi dengan pertumbuhan ekonomi sebagai variabel moderating. Penelitian ini merupakan penelitian kuantitatif dengan data sekunder yang berasal dari lembaga terkait seperti BPS, Dinas Sosial, dan Lembaga-lembaga pendamping Bansos. Data yang digunakan yaitu data Time series dari tahun2018-2020. Populasi Penelitian ini yaitu seluruh masyarakat Pucakwangi penerima Bansos PKH dan BPNT dari 20 desa. Dengan mengambil sampel dengan cara Purposive sampling dari 20 desa yang diaudit dikali Kuartalan mendapat sampel 80. Alat analisis yang digunakan menggunakan Eviews. Hasil Penelitian menunjukkan bahwa Program Keluarga Harapan berpengaruh negatif signifikan terhadap kemiskinan. Program Bantuan non tunai berpengaruh negatif dan signifikan terhadap kemiskinan. Program keluarga harapan yang dimoderasi pertumbuhan ekonomi berpengaruh negatif tidak signifikan. Program Bantuan Pangan Non Tunai yang dimoderasi pertumbuhan ekonomi berpengaruh negatif tidak signifikan.

Kata kunci : PKH; BPNT; Kemiskinan; Pertumbuhan Ekonomi. 


\section{Pendahuluan}

Kemiskinan merupakan masalah yang senantiasa akan ada, baik di negara maju maupun berkembang. Ia lazim didefinisikan sebagai ketidakmampuan dalam mencukupi berbagai kebutuhan, mulai dari sandang, pangan, dan papan. Pada titik tertentu, ketidakmampuan tersebut tidak hanya ketidakmampuan untuk mencukupi kebutuhan keluarga; orang yang benar-benar miskin bahkan tidak bisa memenuhi hajat hidupnya sendiri. Namun, dalam sudut pandang Islam, miskin juga bisa disebut sebagai miskin tentang keagamaan duniawi dan akhirat. Kemiskinan juga merupakan suatau keadaan serba kekurangan dalam pemenuhan baik kebutuhan pokok maupun non pokok.(Majid, 2011)

Tabel 1 Data Tingkat Kemiskinan Di Pati

Periode 2015 hingga 2019 Dalam Persen \%

\begin{tabular}{ll}
\hline Bulan dan Tahun & Tingkat Kemiskinan (\%) \\
\hline Bulan Maret 2015 & 11,95 \\
Bulan Maret 2016 & 11,65 \\
Bulan Maret 2017 & 11,38 \\
Bulan Maret 2018 & 9,90 \\
Bulan Maret 2019 & 9,46 \\
Bulan Maret 2020 & 10,08 \\
\hline
\end{tabular}

Macam-macam dari kemiskinan yaitu kemiskinan absolute, kemiskinan absolute dan kemiskinan relatif. Dalam macam-macam kemiskinan memiliki tingkatan dan kedalaman masing-masing. Pemerintah sebagai pelayan masyarakat memiliki tanggung jawab terhadap kesejahteraan masyarakat. Ada beberapa fungsi pemerintah salah satunya adalah fungsi sekunder yang di dalamnya ada fungsi pembangunan dan fungsi pemberdayaan. Dalam upaya mencapai kesejahteraan dengan cara bantuan sosial sebagai upaya mengurangi kemiskinan.

PKH merupakan suatu program bansos yang mempunyai syarat tertentu yaitu bumil, anak balita,anak dalam masa pendidikan yang terkategori sangat miskin untuk berbagai layanan kesehatan dan berbagai fasilitas layanan pendidikan. Bansos PKH diberikan selama 3 bulan sekali. Dimana bansos ini bertujuan untuk membantu masyarakat miskin yang membutuhkan. PKH merupakan program yang diberikan pemerintah dalam rangka miningkatkan pertumbuhan ekonomi yang lebih baik sehingga mengurangi jumplah kemiskinan yang dialami disuatu wilayah.(Singkoh, 2019)

Tabel 2 Data Jumlah Nominal Penerima

ManfaatBansos PKH Berdasarkan Kriteria

\begin{tabular}{ll}
\hline Kategori Ibu Hamil Atau Nifas & 250.000 \\
\hline Kategori Anak Usia Dini O-6 Tahun & 250.000 \\
Kategori Anak SD Sederajat & 75.000 \\
Kategori Anak SMP Sederajat & 125.000 \\
Ktegori Anak SMA Sederajat & 166.000 \\
Kategori Disabilitas & 200.000 \\
Kategori Lansia & 200.000 \\
\hline
\end{tabular}

Sumber Data: Dinas Sosial Kabupaten Pati 2021

BPNT merupakan sebuah bantuan pemerintah berupa Bantuan Non Tunai yang diberikan setiap bulan berupa sembako dan diberikan melalui rekening elektronik yang dipertukarkan melalui e-warung yang ditunjuk dari masing-masing desa. Perencanaan ini 
difungsikan untuk meminimalisasi pengeluaran KPM dengan cara mencukupi sebagian hajat pangan, memformulasikan gizi yang lebih ideal, dan meningkatkan tujuan-waktu mereka untuk memperoleh bantuan pangan. Langkah ini juga mengakomodasi KPM dengan pelbagai opsi dan control untuk mencukupi kebutuhan pangan. Jika bisa terealisasi dengan presisi, program ini akan mendorong tercapainya beragam tujuan pembangunan berkelanjutan — sebagaimana yang dicanangkan bersama (Gultom, et al., 2020).

Tabel 3 Data Anggaran Penerima Bantuan Pangan Non Tunai (BPNT) 2019-2020

\begin{tabular}{llll}
\multicolumn{4}{c}{$($ BPNT) $2019-2020$} \\
No & Desa & 2019 & 2020 \\
\hline 1 & Pucakwangi & 98.120 .000 & 249.800 .000 \\
2 & Mojoagung & 26.620 .000 & 62.000 .000 \\
3 & Lumbungmas & 47.190 .000 & 109.000 .000 \\
4 & Sitimulyo & 50.710 .000 & 107.600 .000 \\
5 & Kletek & 42.790 .000 & 87.000 .000 \\
6 & Terteg & 28.160 .000 & 64.600 .000 \\
7 & Mencon & 22.770 .000 & 55.000 .000 \\
8 & Pelemgede & 22.440 .000 & 53.400 .000 \\
9 & Sokopuluhan & 37.180 .000 & 98.000 .000 \\
10 & Tegalwero & 14.960 .000 & 47.600 .000 \\
11 & Tanjungsekar & 25.300 .000 & 80.400 .000 \\
12 & Plosorejo & 9.460 .000 & 31.200 .000 \\
13 & Karangrejo & 9.460 .000 & 33.400 .000 \\
14 & Grogolsari & 9.350 .000 & 28.600 .000 \\
15 & Jetak & 7.480 .000 & 22.600 .000 \\
16 & Triguno & 12.760 .000 & 75.800 .000 \\
17 & Kepohkencono & 44.110 .000 & 124.600 .000 \\
18 & Bodeh & 17.490 .000 & 55.400 .000 \\
19 & Karangwotan & 27.940 .000 & 69.600 .000 \\
20 & Wateshaji & 22.770 .000 & 54.600 .000 \\
\hline
\end{tabular}

Sumber Data: Dinas Sosial Kabupaten Pati 2021

Pertumbuhan ekonomi adalah peningkatan kemampuan masyarakat dalam menunjang kebutuhan hidup yang meningkat yang bersifat kuantitatif Pertumbuhan Ekonomi merupakan sala satu indikator dalam melihat sebuah kemiskinn, dimana ketika pertumbuhan ekonomi meningkat tingkat kesejahteraan meningkat maka akan sangat berpengaruh terhadap angka kemiskinan di Wilayah tersebut. Dimana pertumbuhan ekonomi merupakan suatu usaha dalam mengurangi jumplah angka kemiskinan ketika pertumbuhan ekonomi meningkat maka kemiskinan akan menurun. (Munika, 2020)

Tabel 4 Riset Gap penelitian terdahulu dalam peneliti an:

\begin{tabular}{llrll}
\hline No & Peneliti & & Variabel & Hasil \\
\hline 1 & Helvine & Gultom, & X1: Bantuan pangan non & Hasil \\
& Paulus & Kindangen, & Tunai (BPNT) & menunjukkan BPNT (X1) \\
& George & M.V. & X2: Bantuan Sosial & berdampak negatif dan \\
& Kawung & & Keluarga Harapan & signifikan pada kemiskinan, \\
& & & Y: Kemiskinan & PKH berdampak positif \\
& & & terhadap kemiskinan, \\
& & & namun tidak signifikan
\end{tabular}


2 Aprilia Saraswati

X1: Program Keluarga
Harapan $(P K H)$
Y: Kemiskinan perspektive
islam
3. Ana Rosaliana, Susi
Hardjati

Edo Pramana Putra,
dkk X1: Bantuan Pangan Non
Tunai (BPNT)
Studi ini

mendemonstrasikan

menunjukkan

memberikan

negatif dan signifikan terhadap pemberantasanpengentasan kemiskinan

Berdasarkan ketepatan tujuan, pelaksanaan program BPNT (XI) di Kecamatan Wonocolo dinilai masih belem efektif (Y) Negatif tidak signifikan.

$\begin{array}{llr}\text { X1: Bantuan Sosial } & \text { Hasil } & \text { Penelitian } \\ \text { Y1: Pertumbuhan } & \text { menunjukkan } & \text { program } \\ \text { Ekonomi } & \text { bantuan } & \text { sosisal } \\ \text { Y2: Kemiskinan } & \text { berpengaruh } & \text { signifikan } \\ & \text { meningkatkan } & \\ & \text { pertumbuhan } & \text { ekonomi } \\ & \text { daerah } & \text { tertinggal } \\ & \text { sedangkan Pertumbuhan } \\ & \text { ekonomi tidak } & \text { signifikan } \\ & \text { mempengaruhi } & \text { tingkat } \\ & \text { kemiskinan } & \end{array}$

\section{KAJIAN LITERATUR Kemiskinan}

Kemiskinan kerap diidentifikasi dengan pelbagai tanda yang menunjukkan kurangnya pemenuhan hidup yang berkualitas, di antaranya sangan, pangan, dan papan. Berdasarkan keterangan Badan Pusat Statistik (BPS), kemiskinan adalah situasi sulit di mana seseorang atau kaum tertentu tidak mampu secara ekonomi, fisik, atau materi untuk memenuhi hajat hidup bahkan yang paling mendasar, yakni makanan dan minuman.. Kemiskinan merupakan masalah serius yang memberikan imbas d iberbagai sektor terutama ekonomi. Islam sendiri menganjurkan umatnya untuk tolong-menolong sesama masyarakat. Peran pemerintah dan masyarakat harus senantiasa serius dalam menguntas kemiskinan (Rosaliana, Ana, \& Hardjati, 2019)

\section{Bansos PKH}

PKH merupakan suatu program sosial yang fokus pada pemberian bantuan bersyarat dari pemerintah untuk keluarga miskin. Meski begitu, manfaat PKH tidak terbatas pada status kemiskinan, melainkan juga bisa dirasakan penyandang disabilitas dan orang lanjut usia. Hal ini ditempuh agar masyarakat mencapai taraf kehidupan yang lebih sejahtera. Perbaikan sosial merupakan amanat konstitusi dan nawacita presiden. PKH merupakan bantuan tunai yang dikeluarkan pemerintah kepada Keluarga Penerima Manfaat (KPM) sesuai kriteria yang sudah diputuskan. PKH diharapkan memberi dampak yang efektif dalam mengurangi kemiskinan (Wiku, et al., 2020). 


\section{Bansos BPNT}

BPNT merupakan suatu program yang dikeluarkan pemerintah secara Non Tunai berupa sembako melalui E-warung menggunakan kartu Elektronik. Untuk perbankan yang bekerjasama dengan BPNT yaitu Mandiri, BTN, BRI, BNI, namun untuk diwilayah pucakwangi tahun 2018-2019 hanya melalui BNI saja namun pada tahun 2020 jangkauan diperluas dengan menambah 1 lagi kerjasama perbankan yaitu BRI. Wilayah pucakwangi sendiri untuk masyarakat penerima manfaat BPNT dalam mengambil Bansos melalui Ewarung yang bekerjasama dengan lembaga perbankan BRI dan BNI. (Akmal, 2020)

\section{Pertumbuhan Ekonomi}

Pertumbuhan Ekonomi merupakan suatu kebijakan dalam mengurangi jumplah Kemiskinan. Pertumbuhan Ekonomi merupakan syarat penting dalam melihat Kemiskinan dimana ketika pertumbuhan ekonomi dari suatu wilayah membaik dan meningkat maka kemiskinan juga akan menurun. Dalam Islam Ekonomi Islam dilihat sebagai suatu strategi yang baik dalam mengurangi Kemiskinan ketika Pertumbuhan Ekonomi Wilayah tersebut juga baik. Ekonomi Islam merupakan alternatif dalam mencapai pemberdayaan dan perwujudan ekonomi yang semakin unggul, sehingga bisa berdampak pada kestabilan ekonomi, terutama dalam meminimalisasi hingga meniadakan kemiskinan secara terstruktur (Iskandar, 2018).

\section{Hipotesis Penelitian}

Berdasarkan Penelitian sebelumnya yang dilakukan Singkoh (2019) tentang pengaruh Bansos PKH terdapat kemiskinan, maka hipotesis penelitian ini yakni:

$\mathrm{H} 1$ = $\mathrm{PKH}$ berdampak negatif signifikan terhadap upaya mengentaskan kemiskinan

Berdasarkan studi Ikhsan (2019) tentang pengaruh BPNT terhadap kemiskinan, hipotesis riset ini yakni: kemiskinan

$\mathrm{H} 2$ = BPNT berpengaruh negatif signifikan terhadap usaha penanggulangan

Berdasarkan studi MS (2017) dengan judul "Pengaruh Pengeluaran Pemerintah Terhadap Pertumbuhan Ekonomi”, hipotesis studi ini yakni:

$\mathrm{H} 3$ = Pertumbuhan ekonomi memoderasi pengaruh antara $\mathrm{PKH}$ terhadap penanggulangan Kemiskinan.

H4 = Pertumbuhan ekonomi memoderasi pengaruh BPNT terhadap pengurangan kemiskinan.

\section{Metode Penelitian}

Jenis Penelitian

Penelitian ini merupakan penelitian kuantitatif yang diolah dengan metode statistik. Sehingga memperoleh hasil signifikansi berupa hubungan antar variabel yang diteliti.

\section{Sumber Data dan Variabel}

Data yang digunakan dalam penelitian ini adallah data sekunder yang berkaitan dengan Data Kemiskinan, Bansos PKH, Bansos BPNT, dan Pertumbuhan Ekonomi di 
Kecamatan Pucakwangi, yang diambil dari Badan Pusat Statistik (BPS), Dinas Soisal, dan Lembaga - lembaga terkait bansos. Berdasarkan penjelasan Sugiyono (2013), data sekunder didefinisikan sebagai jenis data yang tidak langsung memberikan informasi pada pengumpul — dalam konteks ini peneliti, melainkan melalui publikasi dan informasi yang dikeluarkan oleh lembaga tertentu, misalnya dalam bentuk dokumen. Beberapa variabel yang digunakan dalam studi ini sebagaimana berikut:

Variabel Independen $(\mathrm{X})$ yang digunakan penulis dalam penelitian ini adalah:

- Program Keluarga Harapan (PKH). Program Keluarga Harapan merupakan sebuah langkah asistensi atau bantuan sosial yang diperuntukkan kepada keluarga-keluarga dengan spesifikasi atau kualifikasi tertentu-dengan tujuan dasar perubahan taraf kehidupan ekonomi dan sosial. PKH bertujuan mengubah perilaku miskin. Program ini merupakan bantuan yang didasarkan pada kriteria tertentu penerima bansos yang telah diputuskan pemerintah (Yuliani, 2020)

- Bantuan Pangan Non Tunai (BPNT). Bantuan Pangan Non Tunai (BPNT) yakni bantuan dari pemerintah untuk KPM yang telah melewati serangkaian proses administrasi dan verifikasi. KPM merupakan sebagian masyarakat yang dinilai masih membutuhkan pendampingan terutama dari segi material untuk menunjang perekonomian. Tiap bulan, pemerintah menransfer sejumlah dana bantuan (elektronik) yang hanya boleh digunakan untuk membeli pangan di warung tertentu. Warung-warung tersebut sudah berkooperasi dengan bank penyalur yang ditunjuk pemerintah. Program ini merupakan program baru pengganti program sembako (ASPAR, SAKARUDDIN M, 2020).

Variabel terikat yang digunakan penulis dalam penelitian ini adalah:

- Kemiskinan. Seseorang yang miskin bisa diartikan sebagai seseorang yang tidak memiliki apa-apa atau tidak mampu memenuhi hajat hidup bahkan yang paling mendasar seperti makanan layak sekalipun.

Problematika seputar kemiskinan akan selalu dihadapi suatu negara. Miskin merupakan suatu keadaan tidak terpenuhinya kebutuhan papan, pangan lan sandang.(Dinarila Balqis, et al., 2020).

Variabel moderating yang digunakan penulis dalam penelitian ini adalah:

- Pertumbuhan Ekonomi. Pertumbuhan ekonomi dilihat dari PDRB, dimana ketika nilai PDRB suatu wilayah baik maka kemiskinan juga akan berkurang. Pertumbuhan ekonomi bisa diartikan sebagai pergerakan kemampuan dari suatu perekonomian yang menunjuk pada perubahan secara kuantitatif. Dengan ini ketika bansos mampu menurangi kemiskinan diharapakan juga bisa mendongkrak Pertumbuhan Ekonomi (Sukirno, 2015).

- Populasi. Dalam sebuah riset, populasi diartikan sebagai sebuah wilayah generalisasi yang berisi subjek dan objek (penelitian). Ada kualitas dan karakteristik tertentu yang telah ditetapkan periset guna dipelajari, dianalisis, dan disimpulkan. Dalam studi ini, populasi yang diambil yakni masyarakat Pucakwangi yang menerima Bantuan Sosial BPNT dan Bantuan Sosial PKH Periode 2018-2020 Dari Laporan Keuangan Anggaran 20 Desa di Kecamatan Pucakwangi. 


\section{Sampel}

Sugiyono (2013) menjelaskan bahwa sampel merupakan bagian dari jumlah dan karakteristik yang ada pada populasi. Apabila populasi terlampau besar dan peneliti mustahil memeriksa-mempelajari satu per satu, maka sampel bisa diambil dari populasi yang (dianggap) benar-benar representatif. Dalam riset ini, peneliti mengaplikasikan teknik Sampling Jenuh. Dari populasi tersebut dengan menggunakan tahun 2018-2020, maka diperoleh sampel dengan cara merubah data tahunan menjadi kuartalan Data anggaran masing-masing desa yang yang tersedia dilembaga Dinsos dari 20 Desa dijadikan data kuartalan berarti dikalikan 4, jadi total sampel 80.

\section{Metode Analisis Data}

Metode analisis data yang digunakan dalam menghasilkan analisis untuk data Time series sebagai berikut:

- Menentukan variabel - variabel dalam penelitian, penelitian ini menggunakan satu variabel terikat (Y), dua variabel bebas yaitu PKH (X1) dan BPNT (X2) serta variabel (Z) yaitu Pertumbuhan Ekonomi.

- Melakukan Uji Stasioner

- Melakukan Analisis Deskriptif terkait Penelitian.

- Uji Asumsi Klasik (Uji Normalitas, Uji Multikolinearitas, Uji Heterokedaktisitas dan Uji Autokorelasi)

- $\quad$ Uji Statistik (Uji Determinan ( $\mathrm{R}^{2),} \mathrm{Uji} \mathrm{T}$ dan Uji F)

\section{HaSil dan PEMbahasan Analisis Diskriptif}

Penelitian ini menggunakan sampel Kemiskinan, Bansos PKH, Bansos BPNT, dan Pertumbuhan Ekonomi tahun 2018-2020. Dengan Hasil penegujian sebagai berikut:

\section{Tabel 5 Hasil Uji Deskriptif}

\begin{tabular}{llcccc}
\hline Variabel & Mean & Median & Maximun & Minimum & Std.Dev \\
\hline PKH & $1.62 E+10$ & $1.89 E+09$ & $5.15 E+10$ & $1.09 E+09$ & $2.19 E+10$ \\
BPNT & $2.39 E+09$ & $1.75 E+09$ & $4.53 E+09$ & $1.59 E+09$ & $1.10 E+09$ \\
Kemiskin & & & & & \\
$\begin{array}{l}\text { an } \\
\text { Pertumbu }\end{array}$ & 2278.167 & 2068.000 & 3106.000 & 1790.000 & 509.2629 \\
han & & & & \\
Ekonomi & 10773235 & 10736640 & 12363182 & 9936372 & 623595.0 \\
\hline \multicolumn{5}{c}{ Sumber: Data Sekunder, diolah 2021 }
\end{tabular}

Dari Tabel diatas yaitu Hasil Uji Deskriptif Variabel dengan Hasil PKH Mean 1.62E+10, Median 1.89E+09, Maximun 5.15E+10, Minimum 1.09E+09. Sedangkan untuk BPNT Mean 2.39E+09, Median 1.75E+09, Maximun 4.53E+09, Minimum 1.59E+09. Sedangkan untuk Kemiskinan Mean 2278.167, Median 2068.000, Maximun 3106.000, Minimum 1790.000. Sedangkan untuk Pertumbuhan Ekonomi Mean 10773235, Median 10736640, Maximun 12363182, Minimum 9936372. 


\section{Uji Stasioner}

Dalam studi ini, uji stasioner berupa uji unit root pada tingkatan level. Memiliki nilai proposionalitas kurang dari 0,05 . Hasil uji stasioner pada masing-masing varibel di tunjukkan pada tabel berikut ini:

\begin{tabular}{llll}
\multicolumn{4}{c}{ Tabel 6 Hasil Uji Stasioneritas Data } \\
\hline 1. & PKH & 0,0418 & Stasioner \\
2. & BPNT & 0,0299 & Stasioner \\
3. & Kemiskinan & 0,0466 & Stasioner \\
4. & Pertumbuhan Ekonomi & 0,0479 & Stasioner \\
\hline & Sumber: Data Sekunder, diolah 2021
\end{tabular}

Dari Hasil Uji Penelitian data antar variabel bersifat Stasioner.

\section{Uji Statistik}

Dependent Variable: KEMISKINAN

Tabel 7 Hasil Uji Statistik Data

Method: Least Squares

Date: 05/24/21 Time: 20:41

Sample: $2018 Q 12020 Q 4$

Included observations: 60

\begin{tabular}{lllll}
\hline \hline Variable & Coefficient & Std. Error & t-Statistic & Prob. \\
\hline \hline C & 8645.759 & 1663.492 & 5.197356 & 0.0020 \\
Pkh & $-1.92 E-08$ & $6.60 E-09$ & -2.908312 & 0.0270 \\
Bpnt & $-2.82 E-07$ & $8.58 E-08$ & -3.285130 & 0.0167 \\
Pertumbuhan_Ekonomi & -0.000482 & 0.000149 & -3.229095 & 0.0179 \\
Pkhxpertumbuhan_Ekonomi & $-6.01 E-21$ & $6.80 E-21$ & -0.882675 & 0.4114 \\
Bpntxpertumbuhan_Ekonomi & $-6.57 E-20$ & $6.41 E-20$ & -1.023956 & 0.3454 \\
\hline \hline R-squared & 0.857425 & Mean dependent var & 2278.167 \\
Adjusted R-squared & 0.738613 & S.D. dependent var & 509.2629 \\
S.E. of regression & 260.3659 & Akaike info criterion & 14.26891 \\
Sum squared resid & 406742.5 & Schwarz criterion & 14.51136 \\
Log likelihood & -79.61344 & Hannan-Quinn criter. & 14.17914 \\
F-statistic & 7.216634 & Durbin-Watson stat & 1.958706 \\
Prob(F-statistic) & 0.016058 & & & \\
\hline \hline
\end{tabular}

Dari Tabel 4.5 diatas, dibentuklah persamaan regresi sebagai berikut:

Kemiskinan $=8645.759-1.92 E-08$ PKH $-2.82 E-07$ BPNT $-0.000482 P E-$ 6.01E-21 PKH*PE - 6.57E-20 BPNT*PE 


\section{Uji Asumsi Klasik}

Uji Normalitas

Gambar 1 Hasil Uji Stasioneritas Data
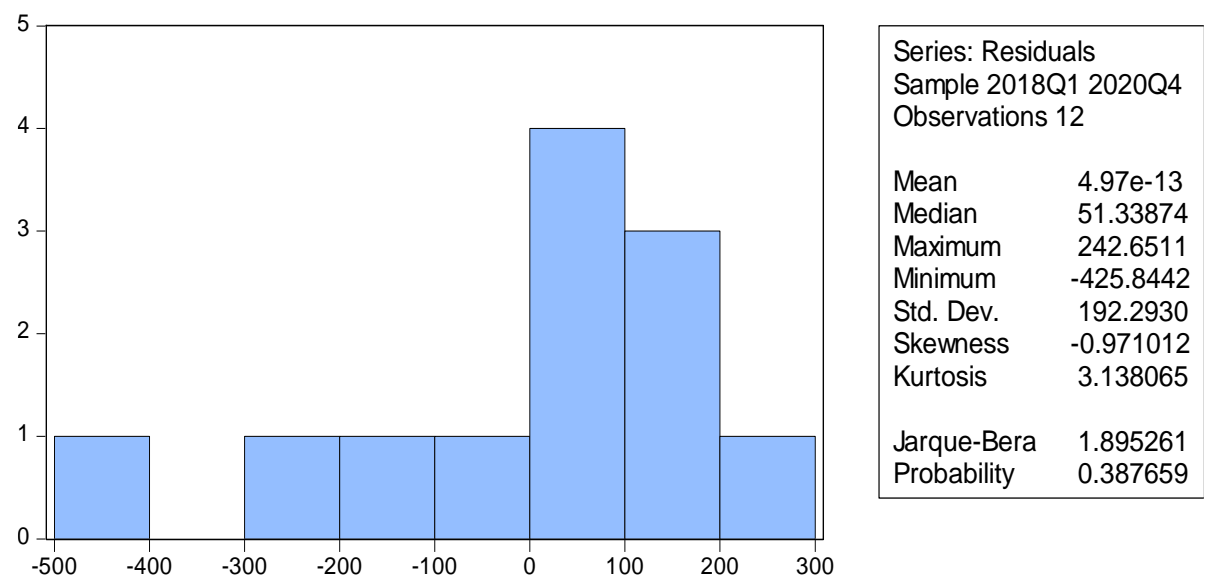

Berdasarkan gambar hasil uji normlitas di atas, diketahui nilai probabilitas JarqueBera adalah $0.387659>0.05$, maka data dipastikan normal

\section{Uji Multikolinieritas}

\section{Tabel 7 Hasil Uji Multikolinieritas}

Variance Inflation Factors

Date: 05/24/21 Time: 20:42

Sample: $2018 Q 12020 Q 4$

Included observations: 12

\begin{tabular}{lrrl}
\hline \hline & $\begin{array}{l}\text { Coefficient } \\
\text { Variance }\end{array}$ & $\begin{array}{l}\text { Uncentered } \\
\text { VIF }\end{array}$ & $\begin{array}{l}\text { Centered } \\
\text { VIF }\end{array}$ \\
\hline \hline Cariable & 2767206. & 489.8402 & NA \\
PKH & $4.36 E-17$ & 5.422201 & 3.397568 \\
BPNT & $7.36 E-15$ & 8.909124 & 1.444521 \\
PERTUMBUHAN_EKONOMI & $2.23 E-08$ & 458.5652 & 1.404086 \\
PKHXPERTUMBUHAN_EKO & $4.63 E-41$ & 4.041114 & 2.760384 \\
NOMI & & & \\
BPNTXPERTUMBUHAN_EK & $4.11 E-39$ & 3.522870 & 1.189096 \\
ONOMI & & & \\
\hline \hline
\end{tabular}

Berdasarkan tabel di atas, diketahui niali variance influence factor (VIF) variabel independen $<10$. Artinya, gejala multikolinieritas bisa dipastikan tidak terjadi 


\section{Uji Autokorelasi}

Tabel 8 Hasil Uji Autokorelasi

Breusch-Godfrey Serial Correlation LM Test:

\begin{tabular}{llll}
\hline \hline F-statistic & 3.900608 & Prob. F(2,4) & 0.1149 \\
Obs*R-squared & 7.932623 & Prob. Chi-Square(2) & 0.0989 \\
\hline \hline " & $=$
\end{tabular}

Berdasarkan tabel di atas, diketahui nilai Prob. F 0.1149 dan Prob. Chi-square $0.0989>0.05$. Artinya, gejala autokorelasi tidak terjadi (pasti).

\section{Uji Heterokedaktisitas}

Tabel 8 Hasil Uji Heterokedaktisitas

Heteroskedasticity Test: Glejser

\begin{tabular}{llll}
\hline \hline F-statistic & 2.174772 & Prob. F(5,6) & 0.1859 \\
Obs*R-squared & 7.733045 & Prob. Chi-Square(5) & 0.1716 \\
Scaled explained SS & 4.110357 & Prob. Chi-Square(5) & 0.5336 \\
\hline \hline
\end{tabular}

Berdasarkan tabel di atas, diketahui nilai Prob. F 0.1859 dan Prob. Chi-square $0.1716>0.05$. Simpulan: gejala heteroskedastisitas tidak terjadi.

\section{Uji Hipotesis}

Uji Koefesien Determinasi $\left(\mathrm{R}^{2)}\right.$

Berdasarkan tes yang dilaksanakan, nilai R-squared diperoleh sebesar 0,5. Hal ini menyatakan bahwa kemampuan dalam menjelaskan pengaruh variasi dependen sebesar $85 \%$. Adapun sisanya, yakni 15\%, dijelaskan oleh variasi lain di luar studi.

\section{Uji T}

Dari Hasil Uji Regresi yang disajikan diperoleh Hasil sebagai berikut:

- Dampak PKH terhadap Kemiskinan nilai probabilitas 0.0270. Sebab nilai probabilitas kurang dari $0,05(\alpha)$, maka koefisien negative. Hal ini berarti PKH berdampak negatif dan signifikan terhadap kemiskinan.

- Dampak BPNT terhadap Kemiskinan nilai probabilitas 0.0167. Sebab skor probabilitas kurang dari 0,05 $(\alpha)$, maka koefisien negatif. Artinya, BPNT berpengaruh negatif dan signifikan terhadap kemiskinan.

- Pertumbuhan Ekonomi yang Memoderasi Bansos Program Keluarga Harapan (PKH) terhadap Kemiskinan nilai probabilitas 0.4114. Sebab skor probabilitas lebih dari $0,05 \quad(\alpha)$ dan koefisien positif, maka PKHXPERTUMBUHAN_EKONOMI tidak berpengaruh terhadap kemiskinan.

- Pertumbuhan Ekonomi yang Memoderasi Bansos Bantuan Pangan Non Tunai (BPNT) terhadap Kemiskinan nilai probabilitas 0.3454. Karena skor probabilitas lebih besar dari 0,05 $(\alpha)$ maka koefisien positif, maka dengan kata lain BPNTXPERTUMBUHAN_EKONOMI tidak berpengaruh terhadap Kemiskinan. 
Uji F (Simultan)

Hasil penelitian menyatakan bahwa nilai prob (F-statistic) ada pada angka $0.016058<0.05$. Simpulan: variabel independen secara bersamaan mampu memberikan dampak (berpengaruh) pada kemiskinan.

Pembahasan Hasil Uji Regresi

Pengaruh Program Keluarga Harapan terhadap Kemiskinan

Berdasarkan hasil penelitian yang telah diperoleh, variabel PKH memberikan dampak negative yang signifikan terhadap kemiskinan di wilayah Pucakwangi, Pati dengan nilai koefiensi -1.92E-08 dan tingkat signifikansi sebesar 0.0270. Dari hasil tersebut, tesis bahwa H1, yakni PKH memiliki dampak negatif cum signifikan terhadap kemiskinan, dapat diterima. Hasil studi ini didukung oleh penelitian Saraswati (2018) yang juga menyatakan PKH berdampak negatif signifikan terhadap kemiskinan.

\section{Program Bantuan Pangan Non Tunai terhadap Kemiskinan}

Hasil penelitian variabel Program Bantuan Pangan Non Tunai berpengaruh negatif signifikan pada kemiskinan di Pucakwangi Pati dengan nilai koefiensi -2.82E07dan tingkat signifikansi sebesar 0.0167. Didukung Hasil Penelitia yang didukung oleh penelitian Trino Ikhsan1, (2019) yang juga menyatakan BPNT berdampak negatif signifikan terhadap kemiskinan

\section{Pengaruh Program Keluarga Harapan terhadap Kemiskinan dengan Pertumbuhan Ekonomi sebagai variabel moderating}

Hasil riset ini mendemonstrasikan bahwa PKH berdampak secara signifikan pada kemiskinan dan pertumbuhan ekonomi di Pucakwangi, Pati dengan nilai koefiensi 6.01E-21 dan tingkat signifikansi sebesar 0.4114. Hasil studi yang didukung oleh penelitian Mahendra (2020), yang menjelaskan PKH dan kemiskinan tidak berdampak negatif dan tidak signifikan terhadap kemiskinan.

\section{Pengaruh Bantuan Pangan Non Tunai terhadap Kemiskinan dengan Pertumbuhan Ekonomi sebagai variabel moderating.}

Hasil Penelitian menunjukkan bahwa variabel Program Bantuan Pangan Non Tunai tidak berdampak signifikan terhadap kemiskinan dan pertumbuhan ekonomi di Pucakwangi Pati dengan nilai koefiensi --6.57E-20 tingkat signifikansi sebesar 0.3454. Didukung Hasil Penelitia yang didukung oleh penelitian yang juga Munika, (2020) menyatakan PKH dan kemiskinan tidak berpengaruh negatif dan tidak signifikan terhadap kemiskinan.

\section{KESIMPULAN}

Berdasarkan hasil Penelitian dapat di simpulkan bahwa Program Keluarga Harapan berdampak negatif signifikan terhadap kemiskinan di Pucakwangi Kab Pati Tahun 2018-2020.Program Bantuan Pangan Non Tunai berdampak negatif signifikan terhadap kemiskinan di Pucakwangi Kab Pati Tahun 2018-2020.Program Keluarga Harapan yang dimoderasi pertumbuhan ekonomi berdampak negatif tidak signifikan terhadap kemiskinan di Pucakwangi Kab Pati Tahun 2018-2020. Program Bantuan Pangan Non Tunai yang dimoderasi pertumbuhan ekonomi berdampak negatif tidak signifikan terhadap kemiskinan di Pucakwangi Kab Pati Tahun 2018-2020. 


\section{REFERENSI}

Akmal, imal alimah. (2020). IMPLEMENTASI PENYALURAN BANTUAN PANGAN NON TUNAI (BPNT) DALAM RANGKA MENINGKATKAN KESEJAHTERAAN MASYARAKAT PRA SEJAHTERA DI KECAMATAN PALLANGGA KABUPATEN GOWA. SKRIPSI.

ASPAR, SAKARUDDIN M, S. D. (2020). IMPLEMENTASI PENYALURAN BANTUAN PANGAN NON TUNAI ( BPNT ) DALAM RANGKA MENINGKATKAN KESEJAHTERAAN MASYARAKAT PRA SEJAHTERA DI KECAMATAN SKRIPSI Oleh IMAL ALIMAH AKMAL PROGRAM STUDI EKONOMI PEMBANGUANAN. Jurnal Washiyah Volume 1 No 2.

Devi Inanta Purwati, M. (2019). MEMODERASIKAH PERTUMBUHAN EKONOMI TERHADAP BELANJA MODAL? (Studi Kasus Pada Pemerintah Kabupaten/Kota di Provinsi Jawa Tengah Periode 2012-2016). Stability: Journal of Management and Business, 2(1). https://doi.org/10.26877/sta.v2i1.4029

Dinarila Balqis, A. S., Iskatrinah, I., \& Hariadi, W. (2020). PELAKSANAAN PROGRAM BANTUAN PANGAN NON TUNAI (BPNT) BERDASARKAN PERMENSOS RI NO. 20 TAHUN 2019 TENTANG PENYALURAN BANTUAN PANGAN NON TUNAI DI DESA KARANGANYAR KECAMATAN KALIBENING KABUPATEN BANJARNEGARA. Jurnal Media Komunikasi Pendidikan Pancasila Dan Kewarganegaraan. https://doi.org/10.23887/jmpppkn.v2i1.133

Gultom, H., Kindangen, P., \& ... (2020). ANALISIS PENGARUH PROGRAM BANTUAN PANGAN NON TUNAI (BPNT) DAN PROGRAM KELUARGA HARAPAN (PKH) TERHADAP KEMISKINAN DI .... JURNAL ....

Iskandar, I. (2018). Islamic Economics as A New Current of Economic Development in Indonesia. Muqtasid: Jurnal Ekonomi Dan Perbankan Syariah, 9(2), 150. https://doi.org/10.18326/muqtasid.v9i2.150-158

Mahendra, A. (2020). Analisis Pengaruh Pengeluaran Pemerintah Sektor Pendidikan Dan Kesehatan, Inflasi Dan Kemiskinan Terhadap Indeks Pembangunan Manusia Dengan Pertumbuhan Ekonomi Sebagai Variabel Moderating Di Indonesia a. 20(September), 174-186.

Majid, M. (2011). MENGENTASKAN KEMISKINAN DALAM PERSPEKTIF EKONOMI

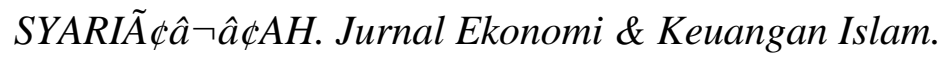

MS, M. Z. (2017). Pengaruh Pengeluaran Pemerintah Terhadap Pertumbuhan Ekonomi Di Provinsi Jambi. EKONOMIS : Journal of Economics and Business, 1(1), 180. https://doi.org/10.33087/ekonomis.v1i1.18

Munika, N. (2020). PENGARUH PENGANGGURAN DAN DANA ZAKAT TERHADAP TINGKAT KEMISKINAN DENGAN PERTUMBUHAN EKONOMI SEBAGAI VARIABEL MODERASI DI INDONESIA 2014-2019 SKRIPSI.

Rosaliana, Ana dan Hardjati, S. (2019). Efektivitas Pelaksanaan Program Bantuan Pangan Non Tunai (BPNT) Di Kecamatan Wonoloco Kota Surabaya. Journal of Chemical Information and Modeling. 
Pengaruh PKH dan BPNT terhadap Kemiskinan dengan Pertumbuhan Ekonomi Sebagai Variabel Moderasi

Sadono Sukirno. (2015). Makroekonomi Teori Pengantar (Ketiga). Rajawali Pers.

Saraswati, A. (2018). Analisis Pengaruh Program Keluarga Harapan (Pkh) Terhadap Pengentasan Kemiskinan Dalam Perspektif Ekonomi Islam. مجلة اسيوط للدراسات البيئة

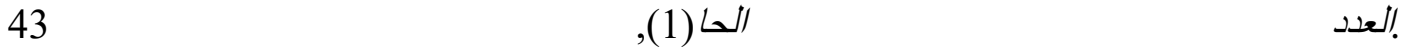
https://repositorio.ufsc.br/bitstream/handle/123456789/186602/PPAU0156D.pdf? sequence $=-$

$1 \&$ isAllowed $=y \% 0$ Ahttp://journal.stainkudus.ac.id/index.php/equilibrium/article/v iew/1268/1127\%0Ahttp://www.scielo.br/pdf/rae/v45n1/v45n1a08\%0Ahttp://dx.doi. org $/ 10.1016 / j$

Singkoh, J. T. T. J. E. K. F. (2019). PROGRAM KELUARGA HARAPAN DALAM PENGENTASAN KEMISKINAN DI KAMPUNG MANUMPITAENG. 3(3), 1-11.

Sugiyono. (2013). Metode Penelitian Pendidikan Pendekatan Kuantitaif, Kualitatif, dan R\&DSugiyono. 2013. "Metode Penelitian Pendidikan Pendekatan Kuantitaif, Kualitatif, dan R\&D." Metode Penelitian Pendidikan Pendekatan Kuantitaif, Kualitatif, dan R\&D. https://doi.org/10.1. In Metode Penelitian Pendidikan Pendekatan Kuantitaif, Kualitatif, dan R\&D.

Trino Ikhsanl, D. Z. M. H. \& F. M. N. M. . (2019). HUBUNGAN PELAKSANAAN BANTUAN PANGAN NON TUNAI (BPNT) DENGAN KESEJAHTERAAN MASYARAKAT MISKIN DI GAMPONG KUTATINGGI, ACEH BARAT DAYA Trino.

Wiku, F., Rotinsulu, T. O., \& ... (2020). ANALISIS PENGARUH BANTUAN SOSIAL (PKH DAN KUBE) TERHADAP TINGKAT KESEJAHTERAAN MASYARAKAT DI KABUPATEN MINAHASA TENGGARA. JURNAL ....

Yuliani, M. (2020). EFEKTIVITAS PENGELOLAAN PROGRAM KELUARGA HARAPAN ( PKH ) UNTUK PENINGKATAN KESEJAHTERAAN MASYARAKAT MISKIN PADA SKRIPSI Oleh : Monika Yuliani NIM : 210716058 Pembimbing : 